\title{
SPIRITUAL AND MORAL RECOVERYOF A STUDENT'S PERSONALITY IN THE COURSE OF STUDYING DISCIPLINES OF THE SOCIAL-HUMANITARIAN CYCLE
}

\author{
Tamara Tyurina (Lviv)
}

Lviv Polytechnic National University, Lviv, Ukraine

- Professor of Department of Sociology and Social Work

\begin{abstract}
Ukrainian society are characterized, as well as one of the possible ways out of the spiritual crisis: spiritual and moral recovery of an individual, since spiritual health is the guarantee of social, mental and physical health of the person and, accordingly, of society (on information-energy level Man - Society Earth - Universe is a single system, all components of which are closely interconnected, interact and influence each other).
\end{abstract}

Aim: To show the role and importance of disciplines of the social and humanitarian cycle in the process of spiritual and moral recovery of student youth, since in the future they will determine the Ukrainian society's spiritual state and direction of development.

Methods: The article uses theoretical analysis of scientific sources on the problem of the research over the past 10 years.

The results of the study can be used for lecturing on the courses "Social Pedagogy", "Introduction to the Specialty "Social Work", "Spiritual and Moral Values of the Social Worker", "Human's Behavior in Social Space", philosophy, general and medical psychology, etc.

Practical importance: the author's personal contribution is to spiritually saturate the content of lectures of the relevant disciplines of the social and humanitarian cycle, aimed at both the awareness of the role of spirituality in the life of a man and society, and at the formation of student youth's inner need for spiritual self-knowledge and self-spiritualization.

Modern Ukrainian society is almost on the verge of self-destruction. The decline of the spiritual and moral level of the younger generation, the negative information and energy environment, the spiritless type of culture, the propaganda of self-centrism, pragmatism, the cult of cruelty, physical power, permissiveness, alienation of man from his own inner world and spiritual needs, little understanding of the system of essential values, inability to prioritize them and that is why focusing on self-affirmation through material well-being and successful career (and thus superiority over people), the loss of ideals and humanity in man, - all these have led to the spiritual and moral decline and devastation of the youth, and, in line with the deep spiritual crisis of our society: its dehumanization and primitivization.

The crisis of spirituality is the most dangerous crisis that has gripped Ukrainian society: the soul of the nation declines, losing their purity and luminosity. People do not see the future, lose 
ideals, do not feel themselves as a part of the World and their kinship with it, their mission on the Earth as a Man, which leads to the loss of the ecology of the soul (term A. Moles, 2008), the destruction of the spiritual and mental structure of man, to degradation and self-destruction of the individual and, accordingly, the spiritual health of the nation (Tyurina, 2017, p.119-132).

Gustave Le Bon warned that "nation can lose a very much, suffer incredible disasters and be able to rise. But it will lose everything; it will never rise if it has lost its soul” (Le Bon, p. 10).

Therefore, the key problem facing us today is to prevent the spiritual and mental destruction of the personality, to promote his/ her spiritual and moral recovery, since spirituality is the essence of the person and the spiritually developed personality lives a creatively rich life, strives to embody Spiritual principles in Genesis through his/ her behavior and actions, aimed at developing, improving oneself and the world, contributing to the spiritual and moral consolidation of society.

According to the V. Vernadsky's theory and modern information and energy paradigm a person is a complex bioinformatics-energy system, which contains not only a dense body, but also subtle-material bodies (SMB - A. Vasylchuk's term, 2016): spiritual and mental components. The spiritual component of a person is a formative, primary source of his mental and physical nature.

M. Goncharenko presented structural organization of man in the form of a pyramid, the basis of which is the physical body, the mental component of health is the middle part of the pyramid and the spiritual component - the top of the pyramid. Based on this structural organization, the valeology developed tactics of cognition, the vector of which is directed from the physical component to the top (spiritual), and the tactics of recovery is directed from the top (spiritual component) to the base of the pyramid, i.e. somatic (physical) health (Goncharenko, 2017, p. 49).

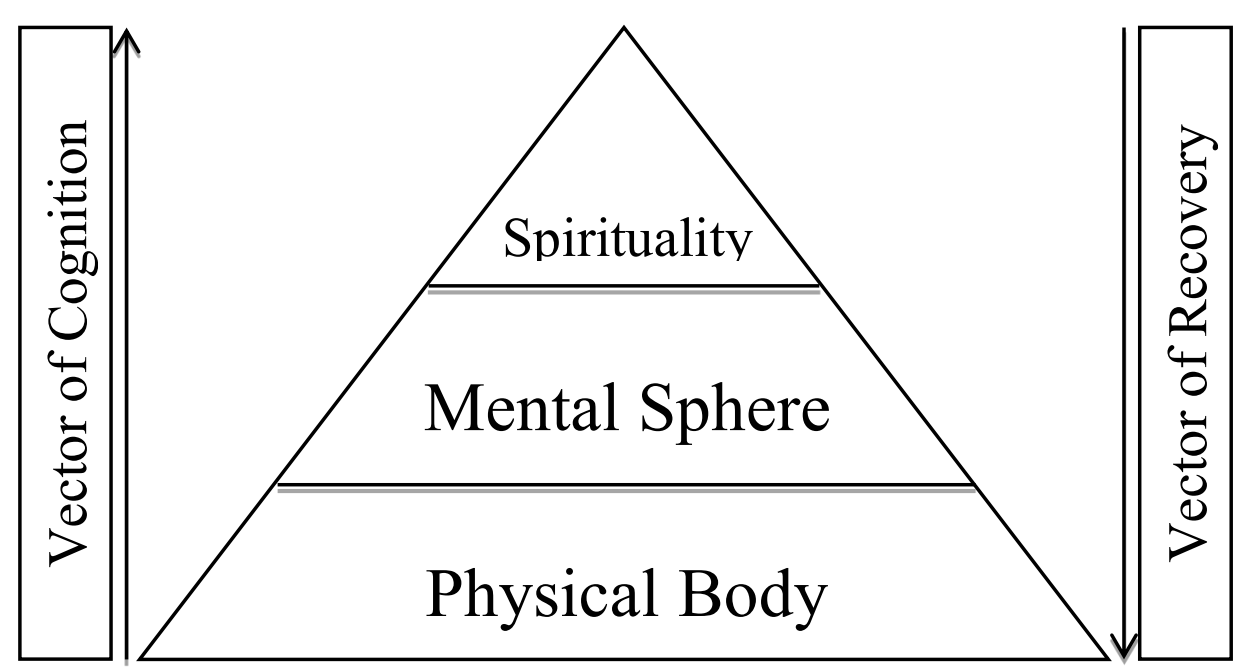

Valeological Tactics of Cognition and Recovery by M. Goncharenko 
Therefore, spiritual health is the determining factor of mental and physical health, the pinnacle of this hierarchy.

The spiritual revival of the Ukrainian society will be possible if the emphasis in the pedagogical process is shifted to the spiritual self-awareness and self-improvement, purposeful selfdevelopment of the individual through the reorientation of the purpose and content of all levels of the modern education to the development of the new generation's spirituality.

In our opinion, special attention should be paid to students, since student youth are the spiritual and creative potential of the nation, the driving force of social changes and transformation. And in a few years the today's students will determine the spiritual and moral level and direction of the evolution of our state.

Therefore, developing the student youth's spirituality is one of the most important factors in the gradual spiritual and moral recovery of the Ukrainian society.

In our opinion, the following disciplines of the social and humanitarian cycle will play a fundamental role in the formation of student youth's spirituality: "Pedagogy of Spirituality", "Problems of Spiritual Self-Development of the Personality", "Introduction to the Specialty "Social Work", "Spiritual and Moral Values of the Social Worker", "Social Pedagogy", "Human's Behavior in Social Space", etc., where special attention is given to the students' awareness of the role and importance of spiritual self-development both in the life of each individual, society, humanity, and preservation of civilization in general, focused formation of inner motivation of students on spiritual self-cognition and self-improvement, ways of spiritual and emotional self-development and selfinspiration (Tyurina, 2018, p.21).

Conclusion: Consequently, the content of the spiritual-oriented disciplines of the socialhumanitarian cycle presents great opportunities to unlock and develop the spiritual potential of the individual, aimed at ennobling, spiritualizing the soul of a person through acquiring knowledge, infused with conscience (Krymskyi's term, 2011), and consequently at the harmonization and spiritual and moral recovery of the "human" system at all levels, thereby contributing to the spiritual recovery and progress of man and humanity.

Keywords: spiritual crisis, spiritual and moral recovery of the individual, spiritual-oriented disciplines of the social-humanitarian cycle.

\section{References}

Vasylchuk A. L. (2016) Enioanatomy of subtle-material bodies of a man: manual. Lviv: SP Soroka T.B. (ukr).

Vernadsky, V. (2002), Biosphere and noosphere, Rolf, Moscow. (rus) 
Goncharenko, M. S. (2017). Sinergistical worldview of modern development of the World and man status: monograph. Kharkiv: FOP Panov A. M. (ukr).

Krymskyi, S. (2011). Interview. Retrieved from ut.net.ua, 2011, March 25. (ukr).

Le Bon G. The Psychology of Peoples. - URL:

http:www.lib.ru/POLITOLOG/LEBON/pshologia.txt.

Moles, A. (2008). Sociodinamics of culture. Moscow: LKI. (rus).

Tyurina, T. G. (2018). Development of spirituality of students in the context of noospheric education. (Abstract of the Dissertation for the degree of Doctor of Pedagogical Sciences). Volodymyr Dahl East Ukrainian National University, Kyiv (ukr).

Tyurina, T. G. (2017), The education of students' spirituality in the noosphere dimension, Lviv Polytechnic Publishing House, Lviv. 